\title{
Microbial Investigations of Surface Microlayers, Water Column, Ice and Sediment in the Arctic Ocean* $^{*}$
}

\author{
Björn Dahlbäck, Lars Å. H. Gunnarsson, Malte Hermansson and Staffan Kjelleberg
}

Department of Marine Microbiology, Botanical Institute, University of Göteborg, Carl Skottsbergs Gata 22, S-413 19 Göteborg, Sweden

\begin{abstract}
A microbiological study was conducted in the area north and northeast of Svalbard, Arctic Ocean. Samples were taken in surface microlayers, ice, water column (down to $300 \mathrm{~m}$ ) and sediment (maximum depth $3920 \mathrm{~m}$ ). ATP-content in the upper $100 \mathrm{~m}$ was between 8 and $80 \mathrm{ng} 1^{-1}$; total bacterial numbers varied between 0.4 and $4.4 \quad 10^{5} \mathrm{ml}^{-1}$. Ice-samples contained high amounts of ATP (max. 120 $\mathrm{ng} 1^{-1}$ ). Bacteria accumulated at the air-sea interface (surface microlayers) at concentrations 130 to 300 times those in subsurface water Viable counts in the sediment ranged between 100 and $3 \cdot 10^{5} \mathrm{~cm}^{-3}$. The degradation potential of 716 bacterial isolates was measured with 6 different media. A capacity index, $C_{\mu}$, measuring the capacity of a group of isolates to degrade certain substrates was determined for the various strata. Bacterial sulfate reduction was measurable in the sediment at the 3 shallowest stations. The data are discussed and compared to those obtained in other marine environments.
\end{abstract}

\section{INTRODUCTION}

The arctic biota lives in an environment with unique features: low temperatures, long periods of complete darkness, and ice-cover. To a large extent, these govern the structure of the local marine ecosystem. Microorganisms have adapted to this extreme milieu. Microbiological studies in the Arctic are scarce; they have been performed north of Alaska and Canada (Boyd and Boyd, 1963; Kaneko et al., 1978) and in the northern Norwegian Sea (Norkrans and Stehn, 1978). Very few microbiological investigations have extended into the deep Polar basin (Kriss, 1963). Microbiological investigations in the central Arctic became possible in July and August 1980 when the Swedish ice-breaker 'Ymer' performed a multidisciplinary expedition in the area north and northeast of Svalbard (first leg).

The aim of this study was to make microbiological observations at various strata, from the surface microlayers down to the sediment in the Polar basin, along the track of the cruise. Microbial numbers and biomass were measured, as well as the bacterial degradation potential of organic matter. Sulfate reduction rates were determined in sediment samples as a measure of in situ bacterial activity.

\footnotetext{
- Contribution from the Ymer-80-expedition
}

\section{MATERIALS AND METHODS}

\section{Investigation Area}

Sub-zero water temperature in the surface water and below the warmer Atlantic inflow was a common situation. On average the salinity increased from $33 \% \mathrm{~S}$ in the surface water to $34.9 \% \mathrm{~S}$ in the deep waters (data from Dept. of Oceanography, University of Göteborg, Sweden). Ice conditions varied along the cruise. Between Svalbard and Frans Josef Land there was an area with drifting ice. This ice seems to be first year ice and was about one to $1.5 \mathrm{~m}$ thick. Approximately north of Latitude $80^{\circ}$ we encountered a covering icefield of multiyear ice with a thickness of 1 to $3 \mathrm{~m}$ (E. Palosuo, pers. comm.).

\section{Sampling}

The map (Fig. 1) shows the investigation area and sampling stations. Coordinates and bottom depths are listed in Table 1. Water samples were taken with Sterile Bag Samplers ('Butterfly', General Oceanics, Miami, Fl., USA). Subsamples were taken within $2 \mathrm{~h}$, preventing any significant increase in the temperature of the samples. Maximum depth at which water samples were taken was $300 \mathrm{~m}$. The sediment was sampled 
Table 1. Coordinates, bottom-depth and sampling sites (surface microlayers, ice, water column, sediment) listed for each station

\begin{tabular}{|c|c|c|c|c|}
\hline Station & $\begin{array}{l}\text { Latitude } \\
\qquad \mathrm{N}\end{array}$ & $\begin{array}{c}\text { Longitude } \\
\text { E }\end{array}$ & $\begin{array}{l}\text { Bottom-depth } \\
\text { (m) }\end{array}$ & $\begin{array}{l}\text { Samples } \\
\text { from }\end{array}$ \\
\hline III & $80^{\circ} 00^{\prime}$ & $27^{\circ} 47^{\prime}$ & nd. & Surface \\
\hline IV & $80^{\circ} 27^{\prime}$ & $24^{\circ} 58^{\prime}$ & 60 & Water \\
\hline VI & $81^{\circ} 24^{\prime}$ & $23^{\circ} 20^{\prime}$ & 440 & Water \\
\hline VII & $81^{\circ} 35^{\prime}$ & $23^{\circ} 53^{\prime}$ & 1150 & Water \\
\hline IX & $82^{\circ} 20^{\prime}$ & $25^{\circ} 19^{\prime}$ & 3885 & Water \\
\hline XIII & $81^{\circ} 31^{\prime}$ & $26^{\circ} 10^{\prime}$ & 1000 & Surface, ice \\
\hline XVI & $81^{\circ} 36^{\prime}$ & $49^{\circ} 54^{\prime}$ & 275 & Water \\
\hline XVII & $82^{\circ} 21^{\prime}$ & $45^{\circ} 56^{\prime}$ & 400 & Surface, ice \\
\hline XVIII & $82^{\circ} 23^{\prime}$ & $45^{\circ} 08^{\prime}$ & 1045 & Water \\
\hline XIX & $82^{\circ} 32^{\prime}$ & $43^{\circ} 58^{\prime}$ & 2500 & Water \\
\hline $\mathrm{xx}$ & $80^{\circ} 36^{\prime}$ & $41^{\circ} 25^{\prime}$ & 395 & Water \\
\hline XXI & $79^{\circ} 41^{\prime}$ & $33^{\circ} 48^{\prime}$ & 355 & Surface, water \\
\hline MB 8 & $82^{\circ} 20^{\prime}$ & $25^{\circ} 16^{\prime}$ & 3920 & Sediment \\
\hline $\mathrm{MB} 9$ & $81^{\circ} 51^{\prime}$ & $26^{\circ} 35^{\prime}$ & 3270 & Sediment \\
\hline MB 10 & $81^{\circ} 41^{\prime}$ & $26^{\circ} 07^{\prime}$ & 2500 & Sediment \\
\hline MB 11 & $81^{\circ} 31^{\prime}$ & $26^{\circ} 03^{\prime}$ & 855 & Sediment \\
\hline $\mathrm{MB} 12$ & $79^{\circ} 38^{\prime}$ & $33^{\circ} 43^{\prime}$ & 340 & Sediment \\
\hline MB 13 & $80^{\circ} 37^{\prime}$ & $30^{\circ} 03^{\prime}$ & 405 & Sediment \\
\hline MB 15 & $79^{\circ} 20^{\prime}$ & $33^{\circ} 31^{\prime}$ & 240 & Sediment \\
\hline
\end{tabular}

with a MK III Standard Box-corer (collects $0.25 \mathrm{~m}^{2}$ ). After the Box-corer landed on deck, plastic tubes, $5 \times$ $60 \mathrm{~cm}$, were gently pushed into the sediment and sealed at both ends.

The procedure for sampling surface microlayers as described by Kjelleberg et al. (1979) was followed. A Teflon sheet $\left(2.25 \mathrm{dm}^{2}\right.$ ) mounted on a holder was allowed to touch the surface horizontally. Ten sheets, separated by steel bars, were then stored in a stainless steel box containing $100 \mathrm{ml}$ of a sterile four-salts solution (FSS, see below). Surface microlayers samples were taken either from a rubberdinghy or from icefloes well clear of the ship to avoid contamination. We estimated the wind speed to be less than $5 \mathrm{~m} \mathrm{~s}^{-1}$ at all surface samplings. The sample thickness was between

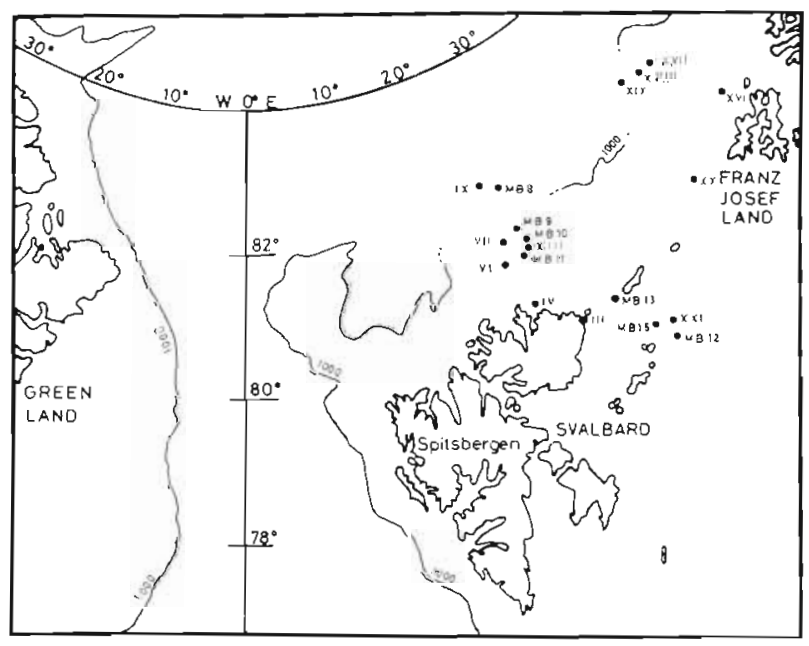

Fig. 1. Investigation area and stations
2 and $3 \mu \mathrm{m}$ as calculated from the amount of water withdrawn. In the ship laboratory a solution of $100 \mathrm{ml}$ $4 \%$ Tween 80 in FSS was added to the box with the Teflon sheets. To suspend the bacteria, the box was shaken for $5 \mathrm{~min}$; aliquots of this solution were used for direct counts (AODC, see below) and viable counts. The ratio of the number of bacteria in the surface microlayers to that in the subsurface water, per unit volume, was designated 'enrichment factor', E.

Ice-cores were obtained with an ice-drill. The lower part $(30 \mathrm{~cm})$ of the core was thawed and analysed.

\section{Enumeration of Bacteria, Aerobic and Anaerobic}

Total numbers of bacteria were determined with acridine orange direct counting (AODC). The method described by Zimmermann et al. (1978) was followed, except that $0.2 \mu \mathrm{m}, 13 \mathrm{~mm} \varnothing$ filters and no silver membrane filter support were used. The microscope was a Leitz Wetzlar Orthoplan equipped with a $200 \mathrm{~W}$ Hg-lamp, red suppression filter $4 \mathrm{~mm} \mathrm{BG} \mathrm{38,} \mathrm{exiting}$ filter, $2 \times \mathrm{KP} \mathrm{490}$, and emission filter, a combination of TK 510 and K 515.

Viable counts (aerobic heterotrophs) and bacterial isolates for the degradation potential assay were obtained by the spreadplate technique using MSWYEmedium. The composition of the MSWYE-medium (Colwell and Kettling, 1974) was 1.0 g yeast extract, 1.0 $\mathrm{g}$ proteose-peptone, $15 \mathrm{~g}$ agar, and $1000 \mathrm{ml}$ four-salts solution (FSS); FSS consists of $24.0 \mathrm{~g} \mathrm{NaCl}, 0,7 \mathrm{~g} \mathrm{KCl}$, $5.3 \mathrm{MgCl}_{2}, 7.0 \mathrm{~g} \mathrm{MgSO}_{4}$, and $1000 \mathrm{ml}$ distilled water (pH 8). Water samples were diluted in FSS or concen- 
trated on $0.45 \mu \mathrm{m}$ filters (Millipore) before being applied to the agar plates. The upper $3 \mathrm{~cm}$ of the sediment cores, subsampled with cut-off plastic syringes, were suspended in FSS and spread on agar plates.

The most-probable-number technique (MPN) using a dilution ratio of 10 and triplicates were used to enumerate anaerobic heterotrophs in 4 strata of the sediment $(0-3,3-6,6-9,9-12 \mathrm{~cm})$. Test tubes with serum bottle necks containing $\mathrm{O}_{2}$-free MSWYE-broth with rezasurin as redox indicator and titaniumcitrate (Zehnder and Wuhrmann, 1976) as reducing agent were inoculated with the sediment suspensions using sterile disposable syringes and needles. Dilutions and inoculations were made according to strict anaerobic technique (Miller and Wolin, 1974). The agarplates (5 parallels) and MPN-tubes were analysed for growth after 9 wk incubation at $4{ }^{\circ} \mathrm{C}$.

\section{Assays for Degradation Potential of Isolates}

Isolates were picked and streaked out 3 times before a multipoint technique was applied to test the lipolytic, proteolytic, amylolytic, and cellulolytic capacity of the isolates at $4^{\circ} \mathrm{C}$. The substrates used were: Tween 80 , glyceryltributyrate ( $L 1, L 2$, lipolytic); gelatine and casein (P1, P2, proteolytic); starch (A, amylolytic) and cellulose. The compositions of the media and details of the multipoint-technique are described by Norkrans and Stehn (1978)

\section{ATP-Analysis}

To discriminate between bacterial and phytoplankton biomass in the ATP-analyses we fractionated the water samples prior to ATP-extraction. The water was filtered through a $200 \mu \mathrm{m}$ polyester mesh preceeding filtration through a $3 \mu \mathrm{m}$ filter (Nuclepore, $47 \mathrm{~mm}$ ) and subsequent filtration onto a $0.45 \mu \mathrm{m}$ filter (Millipore, $47 \mathrm{~mm}$ ). Salonen (1974) recommends pore-sizes between 2 and $5 \mu \mathrm{m}$ to separate bacteria from phytoplankton and here a $3 \mu \mathrm{m}$ filter was used (Derenbach and Le B. Williams, 1974; Larsson and Hagström 1979). Between 1 and 2.51 were filtered. To shorten filtration time, each $3 \mu \mathrm{m}$ filtered sample was divided and filtered through two $0.45 \mu \mathrm{m}$ filters. Directly after the filtration the $3 \mu \mathrm{m}$ and $0.45 \mu \mathrm{m}$ filters were placed in boiling Tris-EDTA buffer (pH 7.75, $20 \mathrm{mM}$ Tris, 2 mM EDTA; Lundin and Thore, 1975) and extracted for $5 \mathrm{~min}$. The extracts were deep-frozen until analysed 2 mo later. ATP in sediment samples was extracted according to the method of Hodson et al. (1976). ATP content of extracts was determined by the luciferinluciferase method (Holm-Hansen and Booth, 1966).
Internal standards were added to the extracts and the amount of ATP determined in a Packard Luminometer Mod. 6100.

\section{Determination of Sulfate Reduction Rate}

Sulfate reduction rate was determined using the ${ }^{35} \mathrm{SO}_{4}^{-}$core-injection method (Jørgensen, 1978). Tubes ( $2.6 \mathrm{~cm}$ wide) were pushed into the $5 \mathrm{~cm}$ wide sediment cores. Triplicates were taken at each station. Carrier-free ${ }^{35} \mathrm{SO}_{4}^{-}(2 \mu \mathrm{l}, 5 \mu \mathrm{Ci})$ was injected into sediment cores with a Hamilton syringe at $3 \mathrm{~cm}$ intervals through 4 pre-drilled silicone-sealed holes. After incubation on deck for a maximum of $30 \mathrm{~h}$, at the most $5 \mathrm{C}^{\circ}$ above in situ temperature, the labeled cores were deep-frozen. In the ship-laboratory the cores were cut in $3 \mathrm{~cm}$ segments and transferred to serum bottles containing $20 \mathrm{ml} 10 \%(\mathrm{w} / \mathrm{v})$ zinc acetate and gassed with nitrogen. After 4 to $6 \mathrm{wk}$ the bottles were acidified, the evolved $\mathrm{H}_{2} \mathrm{~S}$ driven off by oxygen-free $\mathrm{N}_{2}$, and precipitated in a zinc solution. An aliquot of the zinc sulfide and of the sulfate-containing solution in the serum bottles was dissolved in Aquassure (NEN) scintillation cocktail and counted in a Packard TriCarb Liquid Scintillation Counter Mod. 3255. A ${ }^{32} \mathrm{~S} /{ }^{35} \mathrm{~S}$ discrimination factor of 1.06 was used.

Sulfide was analysed as methylene blue (Trüper and Schlegel, 1964). Standards were prepared by dilution of a sulfide stock solution under strict anoxic conditions. Reported sulfide concentrations express the sulfide trapped by zinc after acidification of the ${ }^{35} \mathrm{SO}_{4}^{-}$labeled samples. Content of organic matter in the sediment was calculated from the weight loss of material dried at $105^{\circ} \mathrm{C}$ for $24 \mathrm{~h}$ and then ignited at $450^{\circ} \mathrm{C}$ for 5 h. pH and Eh were measured with Radiometer equipment using a combination electrode for $\mathrm{pH}$ and a platinum electrode with a calomel reference electrode for Eh. The electrodes were inserted into the sediment as the core was pushed out of the coreliner by means of a piston. All Eh values are temperature-corrected. Eh values are used as an operational parameter (Whitfield, 1969, 1974) for interpretation of results.

\section{RESULTS AND DISCUSSION}

The discrepancy between bacterial numbers obtained when using plate count and direct microscopic count are well known (e.g. Jannasch and Jones, 1959). We found ratios of AODC: viable count in the range of $4.5 \cdot 10^{2}$ to $6.7 \cdot 10^{4}$. Part of this difference is due to the differences of the response of living bacteria to nutrients in the media. At least 2 types of response can be recognized among marine bacteria. Oligot- 
rophic bacteria are adapted to grow at low substrate concentrations (Hirsch et al., 1979; Kuznetsov et al., 1979; Poindexter, 1981a); they are not able to respond to high nutrient concentrations. On the other hand, copiotrophic bacteria (Poindexter, 1981b) require higher nutrient levels for growth. These bacteria survive in oligotrophic waters by becoming inactive and forming small starved cells (Novitsky and Morita, 1978 ) or by taking advantage of nutrients accumulating, for example, at interfaces (Kjelleberg et al., 1982). Our direct counts and ATP measurements estimated the total bacterial biomass while the viable counts and the determination of degradation potential dealt mainly with copiotrophic bacteria, responding to nutrients in the medium and increasing the cell volume. Extremely small bacteria, known to be present in aquatic habitats (Anderson and Heffernan, 1965; Zimmermann et al., 1978; Fuhrman, 1981) can be difficult to detect using direct counting technique. This might possibly be reflected in the lack of correlation between the AODC and ATP (see below).

According to definitions by Morita (1975) no distinction between psychrophiles and psychrotrophs could be made, as we only used $4^{\circ} \mathrm{C}$ as incubation temperature.

\section{Surface Microlayers}

The air-sea interface is known to act as an accumulation layer for various chemical compounds and microorganisms (Harvey, 1966; Parker and Barsom, 1970;

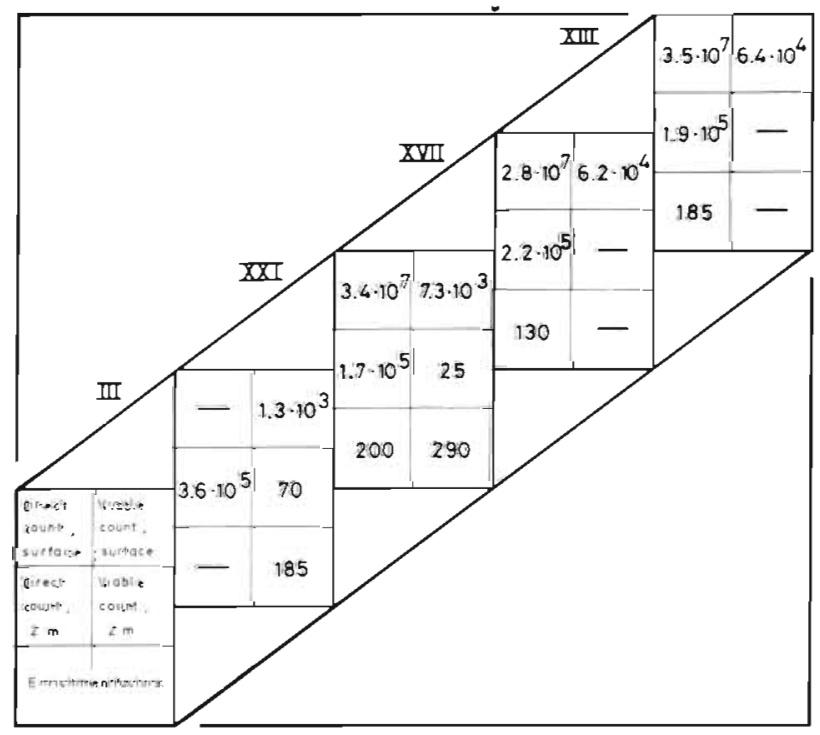

Fig. 2. Enrichment of bacteria in surface microlayers at 4 stations (roman numerals). Numbers of bacteria $\left(\mathrm{mI}^{-1}\right)$ are listed inside squares. Enrichment factors $(E)$ are calculated as ratio between numbers of bacteria volume ${ }^{-1}$ surface microlayers and subsurface water
Norkrans, 1980). We found accumulation of bacteria at this interface at all sampled stations, with enrichment factors (see M. M.) in the range 130 to 290 (Fig 2). Enrichment factors between 12 and 1170 (Kjelleberg et al., 1979) and between 6 and 360 (Dahlbäck et al., 1981) at stations along the Swedish west coast have been reported. The possible difference in the AODC: viable count ratios between surface microlayers (in the order of $10^{3}$ ) and subsurface water (in the order of $10^{4}$ ) might indicate competitive advantage for copiotrophic type bacteria at the interface.

\section{Water}

On average, $45 \%(45 \pm 15, \mathrm{SD}, \mathrm{n}=23)$ of the ATP in the water was found on the $0.45 \mu \mathrm{m}$ filter. No recognizable correlation was detected between the direct counts of bacteria and the amounts of ATP in the $0.45 \mu \mathrm{m}$ fraction. Fig. 3, therefore, presents the total ATP concentrations $(0.45 \mu \mathrm{m}$ fraction $+3 \mu \mathrm{m}$ fraction $)$ together with the total numbers of bacteria $\mathrm{ml}^{-1}$ at different depths. ATP varied between 8 and $80 \mathrm{ng} \mathrm{l}^{-1}$ which is in the lower range of data compiled by Karl (1980) for marine environments.

In the upper $100 \mathrm{~m}$ of Hudson Bay, Legendre and Simard (1979) found higher values, between 90 and $190 \mathrm{ng}$ ATP\# $\mathrm{l}^{-1}$. ATP data from the Antarctic Ocean, excluding samples taken beneath Ross Ice Shelf, are higher throughout (Holm-Hansen et al., 1977; Azam et al., 1979) than our data from the corresponding north latitudes.

Station XXI showed a pronounced pyknocline at approx. $15 \mathrm{~m}$ and the ATP peak at $16 \mathrm{~m}$ was probably due to bioaccumulation at the interface between the water masses with different density. We believe that the intriguing ATP-peak at Station VII at $100 \mathrm{~m}$ was due to zooplankton. The high amounts of particulate matter collected (as seen on the filters) did not correspond to an increase in bacterial numbers and it is known that particulate organic carbon exists in clouds. Wangersky (1978) concluded that these clouds contain microzooplankton. Except for Station VII, ATP concentrations were lower in samples from below $50 \mathrm{~m}$ compared to those from above $50 \mathrm{~m}$.

The total numbers of bacteria in the water were in the range 0.4 to $4.410^{5} \mathrm{ml}^{-1}$. This is about $1 / 4$ of the numbers found by Kaneko et al. (1978) in the Beaufort Sea but in the same range as reported by Holm-Hansen et al. (1977) for McMurdo Sound in the Antarctic. The lack of correlation between ATP retained at the $0.45 \mathrm{~m}$ filter and total bacterial numbers might, apart from the possible existence of very small bacteria as mentioned above, be due to the use of fractionated filtration, a procedure which presents several problems. There is 


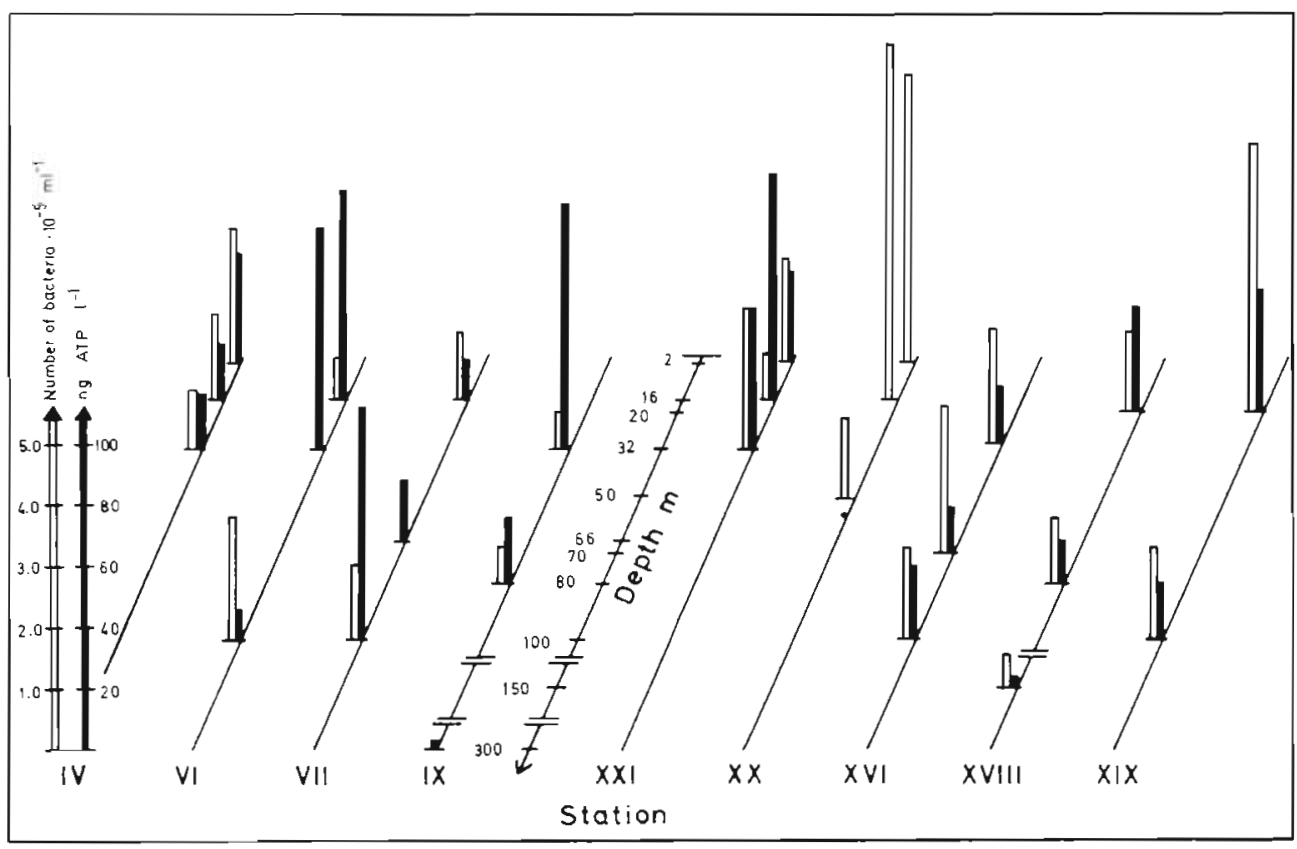

Fig. 3. Concentration of ATP, ng $\mathrm{l}^{-1}$ (filled bars) and total numbers, $10^{5} \mathrm{ml}^{-1}$ (unfilled bars) in water samples

no absolute size limit between bacteria and phytoplankton, furthermore bacteria adhere to particles which are retained by large pore size filters.

Viable counts varied between 5 and $75 \mathrm{ml}^{-1}$ which is more than a thousand times lower than in the Beaufort Sea (Kaneko et al., 1978) which reflect a difference in the bacterial concentration between the central Arctic Ocean and a coastal arctic area. The reports of viable counts in the central Arctic Ocean (Kriss et al., 1967) and the Antarctic Ocean (Wiebe and Hendricks, 1974) are comparable to our results.

\section{Sediment}

Viable counts of aerobes were in the range $3.7 \cdot 10^{3}$ to $3.0 \cdot 10^{5} \mathrm{~cm}^{-3}$ of the upper $3 \mathrm{~cm}$ of sediment (Table 2). Sediment from below $3000 \mathrm{~m}$ revealed the lowest bacterial density. In samples from the deepest station $(3920 \mathrm{~m}$ ) the numbers of aerobes (as well as the number of anaerobes) were below our detection limit. However, the ATP content was $>0.05 \mathrm{ng} \mathrm{cm}^{-3}$ wet sediment. The pronounced difference in bacterial density between MB 9 and MB 8 is remarkable. The availability of energy as degradable matter does not seem to be the limiting factor on a quantitative basis, since stations having the same percentage of organic matter do not reveal such low bacterial numbers. A tentative hypothesis would be that there is a 'biological front' to the deeper parts of the Arctic Basin where low bacterial densities prevail. Kriss (1963) reported hundreds of heterotrophic bacteria $\mathrm{g}^{-1}$ of sediment at a station near the North Pole (4116 meters depth) which could be in agreement with our suggestion.

Except at the deepest station, the numbers of aerobic bacteria in the surface sediment far exceeded those in the water. At depths around $3000 \mathrm{~m}$, Norkrans and Stehn (1978) found an average of $1.5 \cdot 10^{3}$ viable counts $\mathrm{ml}^{-1}$ of sediment from the Spitsbergen and the Greenland basins. This is close to our viable counts at MB 9 $(3270 \mathrm{~m})$. Since identical enumeration procedure was followed we suggest that there is a similarity in bacterial densities between the 2 adjacent deep-sea areas. As expected, bacterial densities in the investigated sediment were lower than those obtained from the Beaufort Sea. Kaneko et al. (1978) report an average of $4.3 \cdot 10^{6}$ viable counts $\mathrm{ml}^{-1}$ sediment from this coastal area. Ten to 100 times less anaerobes than aerobes were found at Stations MB 11 and $M B 10$, and the numbers of anaerobes decreased with depth in the sediment.

At the 3 shallowest stations, bacterial sulfate reduction was detected below $3 \mathrm{~cm}$ at rates in the lower range of the data from other areas (Goldhaber and Kaplan, 1975). Acid-soluble sulfide was found at the same levels at 2 of these 3 stations, and the Eh minima coincided with sulfate reduction. The sulfate reducers have been shown to play a key role in the anaerobic mineralization of organic matter in marine sediments (Jørgensen, 1977) and oxygen is likely to be restricted to the uppermost part of the sediment (Revsbech et al., 1980). We cannot conclude that sulfate reduction does not exist at the deeper stations. Due to the generally oxidized conditions and to the long times involved in 
Table 2. Results of sediment analyses

\begin{tabular}{|c|c|c|c|c|c|c|c|}
\hline $\begin{array}{c}\text { Station } \\
\text { (bottom-deptin) }\end{array}$ & $\begin{array}{l}\text { Depth } \\
\text { (cm) }\end{array}$ & $\begin{array}{c}E h \\
(m V)\end{array}$ & $\begin{array}{c}\text { Organic } \\
\text { matter } \\
(\% \text { dry wt })\end{array}$ & $\begin{array}{c}\mathrm{No}^{\mathrm{a}} \\
\text { anerobic } \\
\text { bacteria } \\
\left(\mathrm{cm}^{-3}\right)\end{array}$ & $\begin{array}{c}\text { No. }{ }^{-1} \\
\text { anearobic } \\
\text { bacteria } \\
\left(\mathrm{cm}^{-3}\right)\end{array}$ & $\begin{array}{l}\text { Sulfate }^{a)} \\
\text { reduction rate } \\
\text { (nmol } \mathrm{SO}^{=} \\
\left.\mathrm{cm}^{-3}, \mathrm{~d}^{-1}\right)\end{array}$ & $\begin{array}{l}\text { Sulfide }{ }^{a} \\
\text { conc. } \\
(\mu \mathrm{mol} \\
\left.\mathrm{cm}^{-3}\right\}\end{array}$ \\
\hline $\begin{array}{l}\text { MB } 15 \\
(240 \mathrm{~m})\end{array}$ & $\begin{array}{l}0-3 \\
3-6 \\
6-9 \\
9-12\end{array}$ & $\begin{array}{l}+450 \\
+260 \\
+200 \\
+210\end{array}$ & d) & & & $\begin{array}{l}-\mathrm{cl} \\
- \\
0.2 \\
-\end{array}$ & $\begin{array}{l}- \\
- \\
- \\
-\end{array}$ \\
\hline $\begin{array}{l}\text { MB 12 } \\
(340 \mathrm{~m})\end{array}$ & $\begin{array}{l}0-3 \\
3-6 \\
6-9 \\
9-12\end{array}$ & $\begin{array}{l}+470 \\
+290 \\
+150 \\
+100\end{array}$ & $\begin{array}{l}6.8 \\
5.4 \\
4.8 \\
4.1\end{array}$ & & $\begin{array}{l}4.6 \quad 10^{3} \\
4.6 \quad 10^{2} \\
<60 \\
<60\end{array}$ & $\begin{array}{l}- \\
- \\
0.1 \\
0.2\end{array}$ & $\begin{array}{c}- \\
- \\
0.04^{\mathrm{bl}} \\
0.16^{\mathrm{bl}}\end{array}$ \\
\hline $\begin{array}{l}\text { MB } 13 \\
(405 \mathrm{~m})\end{array}$ & $\begin{array}{l}0-3 \\
3-6 \\
6-9 \\
9-12\end{array}$ & $\begin{array}{l}+270 \\
+130 \\
+100 \\
+\quad 90\end{array}$ & & $1.5 \cdot 10^{4}$ & & $\begin{array}{l}- \\
0.1 \\
1.4 \\
0.7\end{array}$ & $\begin{array}{c}- \\
- \\
0.35 \\
0.56\end{array}$ \\
\hline $\begin{array}{l}\text { MB } 11 \\
(855 \mathrm{~m})\end{array}$ & $\begin{array}{l}0-3 \\
3-6 \\
6-9 \\
9-12\end{array}$ & $\begin{array}{l}+510 \\
+530 \\
+500 \\
+450\end{array}$ & $\begin{array}{l}4.9 \\
4.6 \\
4.2 \\
4.1\end{array}$ & $9.0 \cdot 10^{3}$ & $\begin{array}{l}7.510^{2} \\
7.5 \cdot 10^{2} \\
40 \\
90\end{array}$ & $\begin{array}{l}- \\
- \\
- \\
-\end{array}$ & $\begin{array}{l}- \\
- \\
- \\
-\end{array}$ \\
\hline $\begin{array}{l}\text { MB } 10 \\
(2500 \mathrm{~m})\end{array}$ & $\begin{array}{l}0-3 \\
3-6 \\
6-9 \\
9-12\end{array}$ & $\begin{array}{l}+540 \\
+450 \\
+460 \\
+450\end{array}$ & $\begin{array}{l}5.7 \\
5.3 \\
4.7 \\
4.7\end{array}$ & $3.1 \cdot 10^{5}$ & $\begin{array}{l}4.3 \cdot 10^{3} \\
4.3 \cdot 10^{2} \\
<30 \\
<30\end{array}$ & $\begin{array}{l}- \\
- \\
- \\
-\end{array}$ & $\begin{array}{l}- \\
- \\
- \\
-\end{array}$ \\
\hline $\begin{array}{l}\text { MB } 9 \\
(3270 \mathrm{~m})\end{array}$ & $\begin{array}{l}0-3 \\
3-6 \\
6-9 \\
9-12\end{array}$ & $\begin{array}{l}+450 \\
+450 \\
+460 \\
+460\end{array}$ & $\begin{array}{l}7.2 \\
6.3 \\
6.7 \\
5.4\end{array}$ & $3.7 \quad 10^{3}$ & & $\begin{array}{l}- \\
- \\
- \\
-\end{array}$ & $\begin{array}{l}- \\
- \\
- \\
-\end{array}$ \\
\hline $\begin{array}{l}\text { MB } 8 \\
(3920 \mathrm{~m})\end{array}$ & $\begin{array}{l}0-3 \\
3-6 \\
6-9 \\
9-12\end{array}$ & $\begin{array}{l}+500 \\
+520 \\
+620 \\
+640\end{array}$ & $\begin{array}{l}4.1 \\
3.4 \\
2.6 \\
2.3\end{array}$ & $<10^{2}$ & $\begin{array}{l}<60 \\
<60 \\
<60 \\
<60\end{array}$ & $\begin{array}{l}- \\
- \\
- \\
-\end{array}$ & $\begin{array}{l}- \\
- \\
- \\
-\end{array}$ \\
\hline $\begin{array}{l}\text { d) Per volume we } \\
\text { b) Data based on } \\
\text { c)-under detecti } \\
\text { d) Blanks = no d }\end{array}$ & $\begin{array}{l}\text { diment } \\
\text { ults fron } \\
\text { limit }_{i}<\end{array}$ & $\mathrm{cm}^{-3}$ & alfide and C & in ${ }^{35} \mathrm{~S}^{-}<$ & backgroun & & \\
\hline
\end{tabular}

sampling, incubation and storage of samples before sulfide distillation, the labeled sulfide might have been partly oxidized and the rates therefore underestimated. Water-soluble sulfide was not analysed, but neither the colour of the sediment nor the smell suggested the presence of free sulfide.

Organic matter averaged $6 \%$ of dry weight at the surface and decreased at all stations with the depth of sampling in the sediment (Table 2). Eh values reflect the input of organic matter and the ongoing biological activity (Baas Becking et al., 1960; Pearson and Stanley, 1979). The average Eh values at each of the 4 deepest stations correlates with the values for organic matter; the higher the amounts of organic matter, the lower the Eh values. The deepest station had the highest ratio between Eh and percent organic matter and lowest bacterial density. Moreover, this station had the smallest difference in $\mathrm{pH}$ (not shown) between overlying water and sediment surface, indicating a relative low bacterial activity.

\section{Biodegradation Potential}

The ability of bacterial isolates to degrade various substrates is seen in Table 3 . The following trends were revealed: (1) The proportion of lipolytic active bacteria was highest in all strata, and the amylolytic active bacteria gave the lowest figures. None of the isolates were able to degrade cellulose. This is in agreement with the findings from the Norwegian Sea (Norkrans and Stehn, 1978). Except for P2, the number of isolates on the test plates did not affect the percentages of positive reactions. (2) When comparing the 
Table 3. Degradation potential of bacterial isolates from different strata. Mean values \pm S.D. of the percentages of colonies able to degrade the substrate of the total colonies growing on the plate. For composition of media see M.M. $c_{1}\left(c_{\text {capacity }}\right.$ index) $=$ sum of percentage values given for different substrates at each stratum, divided by the number of substrates tested

\begin{tabular}{|c|c|c|c|c|c|c|c|c|}
\hline \multicolumn{2}{|r|}{ Substrate } & \multirow[t]{2}{*}{ Water ${ }^{a l}$} & \multirow{2}{*}{$\begin{array}{c}\text { Surface } \\
\text { microlayers }\end{array}$} & \multicolumn{5}{|l|}{ Sediment } \\
\hline & & & & Mean $\pm S D^{c l}$ & $\begin{array}{l}\text { MB 9 } \\
3270^{\text {d) }}\end{array}$ & $\begin{array}{l}\text { MB } 10 \\
2500\end{array}$ & $\begin{array}{l}\text { MB } 11 \\
855\end{array}$ & $\begin{array}{c}\text { MB } 13 \\
405\end{array}$ \\
\hline & Lipolytic (L1) & $72 \pm 19$ & $83 \pm 11$ & $61 \pm 15$ & & & & \\
\hline & Lipolytic (L2) & $98 \pm 3$ & $100 \pm 0$ & $77 \pm 18$ & & & & \\
\hline & Proteolytic (P1) & $59 \pm 27$ & $74 \pm 13$ & $42 \pm 28$ & & & & \\
\hline & Proteolytic (P2) & $35 \pm 32$ & $75 \pm 8$ & $15 \pm 17$ & & & & \\
\hline & Amylolytic & $25 \pm 19$ & $14 \pm 15$ & $7 \pm 10$ & & & & \\
\hline & $c_{i}$ & 57 & 69 & 40 & 34 & 38 & 40 & 61 \\
\hline \multicolumn{9}{|c|}{ a) Water isolates taken from samples at different depths at 5 stations } \\
\hline \multicolumn{9}{|c|}{ b) Surface microlayer isolates taken at 3 stations } \\
\hline \multicolumn{9}{|c|}{ c) Mean value of all sediment stations } \\
\hline & Depth in m & & & & & & & \\
\hline
\end{tabular}

sums of the percentages of all media divided by numbers of media ([LI + L $2+P I+P 2+A]: 5)$, there was a difference between the 3 strata. This number, denoted 'the capacity index', $c_{n}$ could be regarded as a measure of the capacity of a group of isolates to degrade the substrates investigated. The same approach has been used by Martin and Bianchi (1980). Isolates from the surface microlayers displayed the highest diversity with regard to degradable substrates; water isolates gave a lower $c_{i}$ value. (3) The sediment isolates from Stations MB9-MB 11, MB 13 showed a negative correlation between their $C_{1}$ and bottom depth. A tentative explanation could be that a more uniform composition of the organic matter exists at the deeper stations due to degradation in the water-column of the sedimenting materials.

\section{Ice}

The highest ATP values, $120 \mathrm{ng} \mathrm{l}^{-1}$ and $90 \mathrm{ng} \mathrm{l^{-1 }}$ respectively, were found in ice-cores (stations XIII and XVII). The corresponding total counts of bacteria were $4 \cdot 10^{4}$ and $2 \cdot 10^{5} \mathrm{ml}^{-1}$. On average, $20 \%(20 \pm 7, \mathrm{SD}$, $\mathrm{n}=4$ ) of the ATP was found on the $0.45 \mu \mathrm{m}$ filter, which should be compared with $45 \%$ for the water samples. This may reflect a higher proportion of large organisms, such as algae, in the ice compared to water. A high chlorophyll content in ice-samples taken during the expedition (L. Edler, pers. comm.) is in agreement with our findings.

The first evidence of microbial life in snow and ice dates back to Aristotle who stated that snow sometimes becomes bright red. From 1555 (Olaus Magnus, 1555) there is a description of snow inhabitated by 'smale creatures', and later Nansen (1906) found ciliates and diatoms in arctic ice-floes. Algal populations in sea-ice have been studied in the Arctic Ocean (Meguro et al., 1966) Horner and Alexander, 1972) as well as in the Antarctic (Bunt and Wood, 1963). Bacterial densities of $9.9 \cdot 10^{4} \mathrm{ml}^{-1}$ sea-ice have been reported from the Beaufort Sea (Kaneko et al., 1978). These values are comparable to our value of $1 \cdot 10^{5}$ bacteria $\mathrm{ml}^{-1}$ thawed sea-ice.

We believe that the organisms within the ice are an important part of the arctic aquatic ecosystem. Griffiths et al. (1978) showed levels of relative microbial activity in melted sea ice that were about the same as that found in seawater. Since the ice presents solid/water interfaces, adhesion of microorganisms and material (Marshall, 1976) must partly explain the formation of an ice-associated microbiota. But a clear picture of the development of the ice community and the seasonal fluctuations of microbial activity within the ice does not exist in literature. It could be that the ice acts as a trap for material that otherwise would sink to the bottom and thereby retains a higher biological activity in the upper photic zone of the Arctic Ocean.

Acknowledgements. We are most grateful to Professor Birgitta Norkrans who initiated this work and supported us all the way through. We gratefully acknowledge the skilful technical assistance of Assa Jouper and Anders Mårtensson. The enthusiasm of the crew of 'Ymer' was a great help. We are also much indebted to the organizers of this expedition.

\section{LITERATURE CITED}

Anderson, J. I. W., Heffernan, W. P. (1965). Isolation and characterization of filterable marine bacteria. J. Bacteriol. 90: $1713-1718$

Azam, F., Beers, J. R., Campbell, L., Carlucci, A. F., HolmHansen, O., Reid, F. M. H., Karl, D. M. (1979). Occurrence 
and metabolic activity of organisms under the Ross Ice Shelf, Antarctica, at station J9. Science, N. Y 203: 451-453

Baas Becking, L. G. M., Kaplan, I. R., Moore, D. (1960). Limits of the natural environment in terms of $\mathrm{pH}$ and oxidationreduction potentials. J. Geol. 68: 243-284

Boyd, W L., Boyd. J. W. (1963). Enumeration of marine bacteria of the Chukchi Sea. Limnol. Oceanogr 8: 343-348

Bunt, J. S., Wood, E. J. F. (1963). Microalgae and Antarctic sea-ice. Nature, Lond. 199: 1254-1255

Colwell, R. R., Kettling, R. C., Jr. (1974). Isolation and characterization of some deep-sea bacteria. In: Colwell, R. R., Morita, R. Y. (eds.) Proceedings of the second United States-Japan conference on marine microbiology. University Park Press, Baltimore, pp. 227-241

Dahlbäck, B., Hermansson, M., Kjelleberg, S., Norkrans, B. (1981). The hydrophobicity of bacteria - an important factor in their initial adhesion at the air-water interface. Arch. Microbiol. 128: 267-270

Derenbach, J. B., Williams, P. J. Le B. (1974). Autotrophic and bacterial production: fractionation of plankton populations by differential filtration of samples from the English Channel. Mar. Biol. 25: 263-269

Fuhrman, J. A. (1981). Influence of method on the apparent size distribution of bacterioplankton cells: epifluorescence microscopy compared to scanning electron microscopy. Mar. Ecol. Prog. Ser. 5: 103-106

Goldhaber, M. B., Kaplan, I. R. (1975). Controls and consequences of sulphate reduction rates in recent marine sediments. Soil Sci. 119: 42-55

Griffiths, R. P., Hayasaka, S. S., McNamara, T. M., Morita, R. $\mathrm{Y}$ (1978). Relative microbial activity and bacterial concentrations in water and sediment samples taken in the Beaufort Sea. Can. J. Microbiol. 24: 1217-1226

Harvey, G. W. (1966). Microlayer collection from the sea surface: a new method and initial results. Limnol. Oceanogr. 11: 608-613

Hirsch, P., Bernhard, M., Cohen, S. S., Ensign, J. C., Jannasch, H. W., Koch, A. L., Marshall, K. C., Matin, A., Poindexter, J. S., Rittenberg, S. C., Smith, D. S., Veldkamp, H. (1979) Life under conditions of low nutrient concentrations. In: Shilo, M. (ed.) Strategies of microbial life in extreme environments (Dahlem Konferenzen Life Sciences Research Report 13). Verlag Chemie, Weinheim, New York, pp. 357-372

Hodson, R. E., Holm-Hansen, O., Azam, F. (1976). Improved methodology for ATP determination in marine environments. Mar. Biol. 34: 143-149

Holm-Hansen, O., Azam, F. Carlucci, A. F., Hodson, R. E., Karl, D. M. (1977). Microbial distribution and activity in and around McMurdo Sound. Antarctic Journal of the United States 12: 29-32

Holm-Hansen, O., Booth, C. R. (1966). The measurement of adenosine triphosphate in the ocean and its ecological significance. Limnol. Oceanogr 11: 510-519

Horner, R., Alexander, V (1972). Algal populations in Arctic sea lce: an investigation of heterotrophy. Limnol. Oceanogr 17:454-458

Jannasch, H. W., Jones, G. E. (1959). Bacterial populations in seawater as determined by different methods of enumeration. Limnol. Oceanogr. 4: 128-139

Jorgensen, B. B. (1977). The sulfur cycle of a coastal marine sediment (Limfjorden, Denmark). Limnol. Oceanogr 22: $814-832$

Jørgensen, B. B. (1978). A comparison of methods for the quantification of bacterial sulfate reduction in coastal marine sediment. 1 Measurement with radiotracer techniques. Geomicrobiol. J. 1: 11-27
Kaneko, T., Roubal, G., Atlas, R. M. (1978). Bacterial populations in the Beaufort Sea. Arctic 31: 97-107

Karl, D. M. (1980). Cellular nucleotide measurements and applications in microbial ecology. Microbiol. Rev. 44 $739-796$

Kjelleberg, S., Humphrey, B. A., Marshall, K. C. (1982). Effect of interfaces on small starved marine bacteria. Appl. environ. Microbiol. 43: 1166-1172

Kjelleberg, S., Stenström, I. A., Odham, G. (1979). Comparative study of different hydrophobic devices for sampling lipid surface films and adherent microorganisms. Mar - Biol. 53: 21-25

Kriss, A. E. (1963). Marine microbiology (Deep Sea), Oliver and Boyd, Edinburgh, London

Kriss, A. E., Mishustina, I. E., Mitskevich, N., Zemtsova, E. V. (1967). Microbial population of oceans and seas. Edward Arnold (Publishers) Ltd., London

Kuznetsov, S. I., Dubinina, G. A., Lapteva, N. A. (1979). Biology of oligotrophic bacteria. Ann. Rev. Microbiol. 33: $377-387$

Larsson, U., Hagström, $\AA$. (1979). Phytoplankton exudate release as an energy source for the growth of pelagic bacteria. Mar. Biol. 52: 199-206

Legendre, L., Simard, Y (1979). Océanographie biologique estivale et phytoplancton dans le sud-est de la baie d'Hudson. Mar. Biol. 52: 11-22

Lundin, A., Thore, A. (1975). Analytical information obtainable by evaluation of the time course of firefly bioluminescence in the assay of ATP. Analyt. Biochem. $66: 47-63$

Marshall, K. C. (1976). Interfaces in microbial ecology, Harvard Univ. Press, London

Mattin, Y. P., Bianchi, M. A. (1980). Structure, diversity and catabolic potentialities of aerobic heterotrophic bacterial populations associated with continuous cultures of natural marine phytoplankton. Microb. Ecol. 5: 265-279

Meguro, H., Ito, K., Fukushima, H. (1966). Diatoms and the ecological conditions of their growth in sea ice in the Arctic Ocean. Science, N. Y. 152: 1089-1090

Miller, T L., Wolin, M. J. (1974). A serum bottle modification of the Hungate technique for cultivating obligate anaerobes. Appl. Microbiol. 27: 985-987

Morita, R. Y. (1975). Psychrophilic bacteria. Bact. Rev. 39: $144-167$

Nansen, F. (1906). Protozoa on the ice-floes of the North Polar Sea. Norw. North Polar Exped. 1893-1896. Sci. Results 5 : (16) $1-22$

Norkrans, B. (1980). Surface microlayers in aquatic environments. In: Alexander, M. (ed.) Advances in microbial ecology, Vol. 4. Plenum Publ. Corp., New Nork, pp. 51-85

Norkrans, B., Stehn, B. O. (1978). Sediment bacteria in the deep Norwegian Sea. Mar. Biol. 47: 201-209

Novitsky, J. A., Morita, R. Y (1978). Possible strategy for the survival of marine bacteria under starvation conditions. Mar. Biol. 48: 289-295

Olaus Magnus (1555). Historia de gentibus septentrionalibus, Rome

Parker, B., Barsom, G. (1970). Biological and chemical significance of surface microlayers in aquatic ecosystems. Bio Science 20: 87-93

Pearson, T H., Stanley, S. O. (1979). Comparative measurement of the redox potential of marine sediments as a rapid means of assessing the effect of organic pollution. Mar. Biol. 53 : $371-379$

Poindexter, J. S. (1981a). Oligotrophy: fast and famine existence. In: Alexander, M. (ed.) Advances in microbial ecology, Vol. 5. Plenum Press, New York, pp. 63-89 
Poindexter, J. S. (1981b). The Caulobacters: ubiquitous unusual bacteria. Microbiol. Rev. 45: 123-179

Revsbech, N. P., Jorgensen, B. B., Blackburn, T H. (1980). Oxygen in the sea bottom measured with a microelectrode. Science, N. Y 207: 1355-1356

Salonen, K. (1974). Effectiveness of cellulose ester and perforated polycarbonate membrane filters in separating bacteria and phytoplankton. Ann. Bot. Fennici. 11: 133-135

Trüper, H. G., Schlegel, H. G. (1964). Sulphur metabolism in Thiorhodaceae. 1. Quantitative measurements on growing cells of Chromatium okenii. Antonie van Leeuwenhoek 30: $225-238$

Wangersky, P. J. (1978). The distribution of particulate organic carbon in the oceans: ecological implications. Int. Revue ges. Hydrobiol. 63: 567-574

Whitfield, M. (1969). Eh as an operational parameter in estuarine studies. Limnol. Oceanogr. 14: 547-558
Whitfield, M. (1974). Thermodynamic limitations on the use of the platinum electrode in Eh measurements. Limnol. Oceanogr. 19: 857-865

Wiebe, W. J., Hendricks, C. W (1974). Distribution of heterotrophic bacteria in a transect of the Antarctic Ocean. In: Colwell, R. R., Morita, R. Y (eds.) Proceedings of the second United States-Japan conference on marine microbiology. University Park Press, Baltimore, pp. 524-535

Zehnder, A. J. B., Wuhrmann, K. (1976). Titanium (III) citrate as a nontoxic oxidation - reduction buffering system for the culture of obligate anaerobes. Science, N. Y. 194: $1165-1166$

Zimmermann, R., Iturriaga, R., Becker-Birck, J. (1978). Simultaneous determination of the total number of aquatic bacteria and the number thereof involved in respiration. Appl environ. Microbiol. 36: 926-935 